Parties desiring to lease the Searles Lake potash lands can therefore now file their applications in the United States land office at Independence, $\mathrm{Cal}$. Copies of the regulations may be procured from the Commissioner of the General Land Office, Washington, D. C.

The Searles Lake deposit is recognized as a large and available source of commercial potash, and two plants are manufacturing potash from this source at present. Saturated brine deposit is the source of potash now being produced.

A number of parties have already filed applications for leases in the Searles Lake region.

Several applications have also been filed for leases to the potash deposits in Wyoming. The potash leasing bill provided that the Secretary of the Interior may issue leases for deposits of potash in public lands in Sweetwater County, Wyoming, which also contains a sub-deposit of coal, on condition that the coal be restored to the United States.

It should be clearly understood that there are two classes of leases allowed under this bill-one is for leases on the two known deposits, Searles Lake and Sweetwater County, Wyoming, and the other is to hunt for deposits where it is not known that there are potash deposits.

Under the part of the act which permits exploration for undetermined deposits of potash a number of permits have been issued for exploration of lands in California, Nevada, and Colorado.

\section{A LETTER FROM FRANCE}

GAS SERVICE

A. P. O. No. 717, A. E. F. April 5,1918

\section{DEAR DR. HERTY}

I am in receipt of your interesting letter of March $13 . \mathrm{Be}$ sure to continue to write me occasionally, for any home chemical news is welcomed by us all. So far, no copies of the Industrial Journal have been received, so I enjoyed the editorial separates.

Colonel Bacon and I are now located about 150 miles from Paris, and are engaged in the organization of a strong Technical Division for the Gas Service, A. E. F. Col. Bacon is Chief, and I, Assistant Chief, of that Division, which attends to all matters chemical, medical, engineering, and ordnance. Capt. Hildebrand is acting director of the Gas Service laboratory, a section of ours which is doing splendid work. So far our laboratory equipment has not been received from the States, but all necessary apparatus and chemicals have been purchased here because of the pressing importance of many of the problems submitted to us. Our officers and men are doing fine work under the conditions and to date about twenty reports have been issued. Copies of these are, of course, sent to Washington. The French scientists are coöperating with us in every way possible, and you will be glad to know that a Paris section of the A. C. S. is under petition.

Colonel Bacon and I have had luncheon with Lieut. Engel several times. At present he is engaged in preparing his American report. His wife is a charming American lady, active in child welfare work here.

All of us are well and working hard.

Kindest regards to you, Sincerely yours,

(Signed) W. A. HAMOR

Best regards to you and my other friends around the Chemists' Club in New York. Wish we could drop in there for a day.

(Signed) R. F. BACON

\section{THE ASSOCIATION OF BRITISH CHEMICAI MANUFACTURERS}

Editor of The Journal of Industrial and Engineering Chemistry:

The attention of my Council has been called to a certain misapprehension which exists in the minds of the public as to the body entitled to speak on behalf of the Chemical Manufacturers of the United Kingdom. In this connection, I would call attention to a paragraph in the Report of the Committee appointed by the Minister of Reconstruction to advise as to the procedure which shotld be adopted for dealing with the Chemical Trade, which reads as follows:

We are, however, of opinion that the Association of British Chemical Manufacturers is the most representative Association of the Chemical Trade at present in existence in this country, and that it does, generally speaking, represent the Trade as a whole.

The address of the Association of British Chemical Manufacturers, is I66, Piccadilly, W. I.

Thanking you for giving publicity to this letter, I am, Yours faithfully, (Signed) G. Mount, Secretary

LONDON, ENGLAND

APRII, 26, 1918

\section{CONSERVATION OF ALCOHOL, GLYCERIN, AND SUGAR AS USED IN MEDICINES}

According to the Official Bulletin of May 2, 1918, Dr. Franklin Martin, member of the Advisory Commission and chairman of the General Medical Board of the Council of National Defense, has issued the following statement:

During the past several weeks there has been considerable discussion throughout medical and pharmaceutical circles relative to the conservation of alcohol, glycerin, and sugar as applied to medicinal products.

Governmental and other authorities interested, realizing that careful consideration should be given the subject, recently met and debated the advisability and necessity of conservation measures from the standpoint of medical needs. In view of the importance of alcohol, sugar, and glycerin in the manufacture of pharmaceutical preparations and of the limited possibilities for the conservation of alcohol and sugar therein, it was deemed advisable to refrain at this time from recommending conservation of sugar and alcohol in so far as their use in pharmaceutical preparations is concerned.

The amount of glycerin used in medicine when compared to the available supply was found to be relatively large, and a committee was appointed to investigate formulas, manufacturing processes, etc., requiring glycerin and to submit plans for the curtailment of the quantity now used in case future developments should make it necessary to adopt conservation measures in relation to medicines.

\section{HIGH-GRADE TECHNICAL MEN AND SKILLED OPER- ATIVES WANTED FOR UNITED STATES ARMY ORDNANCE}

An urgent call for high-grade technical men and operatives to fill war positions in industrial establishments was made today, through the Civil Service, by the United States Army Ordnance.

Salaries ranging from $\$ 1600$ to $\$ 6000$ a year will be paid the men who qualify for the places.

Chemists and chemical engineers; men experienced in the manufacture of gas; mechanical engineers on high pressure apparatus; engineers to take charge of power houses; and foremen of machine shops are needed. Persons of military age accepting appointment will not avoid the obligations of the Selective Service Law.

The Army Ordnance, in issuing its call for these men, is insisting on one point. No applications will be accepted from Government employees or employees of firms or corporations engaged in contracts for the Government or its Allies unless written assent to such application is given by the head of the establishment that might be seriously handicapped in its war work by the loss of the man. 